\title{
Public Order and Security Institutions Competences Which Determine the Working Action Framework of Their Officials. The Case of Hellenic Coast Guard Personnel
}

\author{
Korontzis Tryfon ${ }^{1}$ \\ ${ }^{1}$ Hellenic National Faculty of Local Government (ESTA), Piraeus, Hellas \\ Correspondence: Korontzis Tryfon, Hellenic National Faculty of Local Government (ESTA), 228 P.Ralli Street, \\ 18454, Nikaia, Piraeus, Hellas. E-mail: tmkoront@otenet.gr
}

Received: August 4, 2012 Accepted: September 3, 2012 Online Published: November 29, 2012

doi:10.5539/jpl.v5n4p50 URL: http://dx.doi.org/10.5539/jpl.v5n4p50

\begin{abstract}
The institutions that have been established by the State and supported democracy, guaranteeing the safeguard of citizens individual and social rights. Each institution is governed by structures, which have specific functions concerning its internal structure, organization and administration but also the specific mission which is requested to carry out, in accordance with the existing legal framework as provided in the Constitution, laws, regulations acts, in the legal opinions issued by the Judicial and Prosecutorial Authorities as also in the legal opinions issued by the Council of the State.

In order to be achieved the above there are many institutions which performed - carrying out mainly police duties such as Hellenic Police (HP), Hellenic Coast Guard (HCG), Municipality Police, etc. These institutions and more specifically HP and HCG and in particular, their mission, role, act and their internal administration mechanisms, have been and are often subjected of social criticism but also sometimes subject of social approval.
\end{abstract}

Keywords: public order, security, Hellenic Coast Guard (HCG), council of state, Ministry of Shipping and Aegean (MSA), Code of Public Maritime Law (COPML), judicial police, administrative police, Law Enforcement Agency (LEA)

\section{Introduction}

One of the main public order and security institutions which performs - enforces primarily police functions duties in Hellas, is Hellenic Coast Guard (HCG), a Law Enforcement Agency (LEA), which via headquarters is under the supervision of Ministry of Shipping and Aegean (MSA).

The above corps which consists an armed security corps, military structured, of which its staff has the status of the military according to the Hellenic Military Penal Code (HMPC) (Note 1) beyond the enforcement of competencies which have police character, is consisting the administrative institution of the Merchant Marine and within its mission is concluded the contribution in maritime policy implementation as is determined by the Government, the regulation of items concerning maritime labour, seafarers welfare, maritime transportations, seafarers training etc (Note 2).

For the implementation of legislation concerning Hellenic vessels and crews safety as well as for resolving disputes, have been established Maritime Consular Port Police Authorities in the foreigner aiming to support and to facilitate the Hellenic merchant marine (Note 3).

The structure, organization, function and mission of the HCG are containing in the law 3922/2011 ( $\left.\mathrm{A}^{\prime} 35\right)$, in the Presidential Decree (PD) 67/2011 (A' 149) and PD 94/2012 (A' 149), ministerial decision (MD) 1141.1/04 issued on July 14, 2011 (B' 1611) and the MD with No 1220.3/01/01 issued on April 04, 2001 by the Minister of Mercantile Marine with which was ratified the Port Police Authorities Action Regulation as was supplemented by the MD with No 1220.3/10/2004 issued on April 21, 2004.

HCG personnel as mentioned before is organized military and governed by the provisions which are in force each time for officers, warrant officers and petty officers of Hellenic Navy (HN), to whom are assimilated concerning its situation, criminal jurisdiction and discipline (Note 4). 
Police functions of HCG are divided into administrative and judicial. The first category which constitute generally the police order, perform the administrative function and aims in preserving and protecting public order and security as also in preventing crime. The second falls within the judiciary authority and develop its activities in the field of crime suppression by exercising investigative tasks that help in better and safer exercise of criminal courts jurisdiction.

The purpose of this concise study is the critical provisions description - analysis which setting out the competencies that govern the action of HCG (one of the main LEA of public order and public security in Hellas) and consequently personnel competence that staff it, within the framework of Judicial (Note 5) and Administrative Police competencies exercise, while will be critically described and auxiliary tasks which have been entrusted to it by the State.

\section{HCG Mission}

According to article 2 of law 3922/2011 (A'35) HCG enforce the following competencies:

a. Ensuring public order, which includes general policing enforcement and traffic police.

b. Crime prevention and repression and in particular organized crime involving public and State security enforcement (Note 6).

c. Organization of conditions concerning safe navigation.

d. Search and rescue at sea (Note 7).

e. The protection of maritime environment (Note 8).

f. Taking measures for surveillance, policing enforcement and control of sea borders (Note 9).

g. Ensuring of compliance and enforcement of rules control concerning maritime safety on ships and port facilities, as well as conditions for safe vessels management, in accordance with the institutional framework, which is in force each time, such as the International Ship and Port Facility Security (ISPS) (Note 10) which was ratified by the law 1045/1980 (A' 95) after the amendments which were adopted by the Conference of Contracting Governments of the International Convention on December $12^{\text {th }}, 2002$ and was incorporated in the Hellenic legal order by the PD 56/2004 (A'47) and the International Secure Management (ISM) which was ratified by the law $1045 / 1980$ (A' 95), as was amended and was supplemented by the decision with No 1/1994 of the Conference of the Contracting States to the International Convention for the safety of life at Sea 1974, which was incorporated in the Hellenic legal order by the PD 74/1996 (A' 58).

$\mathrm{h}$. The enforcement control concerning vessels staff requirements.

Additionally according to the paragraph 7 of article 23 of the same law «Regional Services of HCG enforce on the basis of circulars orders and directives competences of other Ministries conferred on them via HCG Headquarters. By a joint decision of the Minister of Citizen Protection (after the publication of the PD 94/2012 is meant the Minister of Shipping and Aegean) and the responsible in case Minister are determined those competences and the way of their enforcement». So far this MD has not been issued.

The enforcement of police power at ports (Note 11) and in the territorial waters, as well as in the Hellenic vessels according to article 5 (Note 12) of the Hellenic Penal Code (HPC) is concluded in the Port Police Authorities competence (Note 13).

A key law for HCG police power enforcement is the legislative decree (LD) 444/1970 (A' 39) «HCG competencies and relationships concerning to the competencies of other security corps». This LD has been amended according to the paragraph 2 of article 14 of law 2881/2001 (A' 16) regarding traffic at port land areas as also in areas that are assimilated with them. More specifically the enforcement of competence for traffic [High Way Code (Traffic Offences)] control at the port areas by Port Police Authorities staff has become exclusive.

Specific difference that occurs with this provision is that becomes exclusive this concrete jurisdiction at the land area of ports, regardless if the ports are fencing or not (Note 14).

Port Police Authorities jurisdiction in accordance with LD 187/73 (A' 261) «Code of Maritime Public Law (COMPL)» is distinguished in administrative and judicial (Note 15). In particular the Port Police Authorities jurisdiction (Note 16) is enforced in a specified area and for a given circle of items (Note 17).

\subsection{Administrative Police}

In the concept of administrative Police is containing the action revealing from the variety of administrative police laws and basically of the police provisions. Here, police sets legal regulations and surveys their implementation. In 
case of their violation, Police impose penalties on the offenders anticipated in administrative laws and police regulations and these are police fines (Note 18).

According to Chapter B', part three of COMPL, in articles 141-157 which are referred to the Administrative Port Police, Port Police Authorities:

a. - Regulate traffic, parking, changing anchorage, anchorage, security, hygiene, cleanliness and general public order in its area of responsibility. At the ports where is based Port Authority responsible on the economic exploitation of the port (Note 19) is required consultation between Port Police Authority and Port Authority for regulating parking, anchorage change and anchoring of vessels arriving for loading or uploading.

b. - Regulate any work that is done at the port, except those which are regulated according to the law by Committees Regulating Loading Uploading Tasks. At the ports of Piraeus and Thessaloniki tasks are regulated by the Port Authority of Piraeus SA (OLP AE) and Port Authority of Thessaloniki SA (OLTH AE) respectively (Note 20).

c. - Ensure that the port is maintained in good condition in order to be ensured vessels mooring.

d. - Exercise health functions, unless there is a particular health service port.

e. - Survey the implementation of legislation concerning Antiquities and public land/properties, for tourist ships, sea tourism, the market police provisions at the area of port as also on the vessels.

f. - Enforce any other activity entrusted with specific laws on police authorities for acts that take place under their jurisdiction.

g. - Cooperate with other competent authorities on issues concerning items of public order and security.

h. - Supervise the proper operation of beacons and lamps in the region and notify immediately the competent service.

i. - Check whether vessels and auxiliary docked vessels located in their area, bear the lights and signals provided by the International Conference on Revision of the International Regulations for Preventing Collisions at Sea 1972 (Note 21).

j. - Supervise the avoiding of using lights on land that can mislead ships.

k. - Report to the competent services any navigational hazard that is not marked on navigational maps and takes every measure to prevent an accident.

1. - Ensure the implementation of legislation for wrecks (Note 22).

m. - Prohibit temporarily for reasons concerning national security or public order, the stay or passing of a vessel with a foreign flag via the Hellenic territorial waters. This prohibition is effected by an order issued by the Minister of Shipping and Aegean after pursuant decision of the Cabinet (Note 23).

n. - It may determine, after consultation with the Port Authority that explicates the port and authorization of the Ministry, the maximum number of permanently employed at the port, vessels and auxiliary docked vessels, when this is not provided by special laws.

o. - Grant specific permission for buildings built or huts and booths in the area of its region. Also Port Police Authorities after approval of the Minister, order the removal or transfer of huts when is necessary for public interest reasons.

p. - Supervise decommissioned vessels and auxiliary docked vessels located in their area and determine the minimum number of guardians and the skills they need to have (Note 24).

q. - Determine the necessary measures that must be taken for fire prevention on vessels, auxiliary docked vessels, buildings and other facilities in port.

r. - They may take punitive measures against fires. In case of fire Port Police Authorities call the fire port brigade, vessels lie in harbor district, rescue vessels and tugs and in emergency situation also the crews of mooring vessels and auxiliary docked vessels as also the port and sea employees in order to assist in extinguishing the fire out.

If emergency case Port Police Authorities can request the assistance of warships that are in the region as also of Military, Police and Fire Authorities which are located in the town in which is based the Port Police Authority.

Also can order or act the anchorage change, stranding and sinking (in absolute necessity) of the burnt vessel when there is a risk for fire transmission to ships or buildings located next to the burnt vessel.

s. - Supervise the exact observance of vessels voyages (Note 25). 
t. - Supervise that vessels during arriving and departing bring their national flag

u. - Issue police provisions with the type of Port Regulation [General (GPR) and Special (SPR)] in order to exercise the administrative police competences (Note 26).

\subsection{Judicial Police}

Judicial police include all those investigative actions which are enforced by police for the implementation of criminal legislation and in accordance with the provisions of the Hellenic Penal Procedure (HPP).

In chapter III, part three of the LD 187/1973 (A' 261) (COMPL), in articles 158-163 are determined the Port Police Authorities investigative tasks. Specifically these are:

a.-Heads of Port Police Authorities and the staff under their commands, officers, warrant officers, and petty officers of HCG until the rank of the first petty officer, enforce in area of their jurisdiction all the rights and duties of general employees investigators in connection with the crimes that have been committed in this (Note 27).

The enforcement of investigative duties is taking place under the supervision of the competent Public Prosecutor and according to HPP provisions (Note 28). Also enforce duties of Public Prosecutor in Magistrates Local Court for faults committed in the area of their jurisdiction.

b.- Port Police Authorities during the enforcement of their interrogative duties can request the assistance of other police authorities and must provide their assistance when requested by them (Note 29).

c.-Port Police Authorities enforce their investigative tasks in merchant vessels and auxiliary docked vessels bearing a foreign flag which are in the port or in the territorial waters of the region (Note 30), when is not otherwise provided by international conventions, in cases that are disturbed or threatened the public order and is requested the Port Police Authority assistance by the master or other person of the vessel.

But, Port Police Authority should invite the relevant Consular Authority to attend during its intervention, except if is an urgent need and the announcement of the intervention can be done at the time of action.

d- Port Police Authorities can act any investigative action on merchant vessels bringing a foreign flag which are in the Hellenic territorial waters, against persons that are prosecuted as also and arrests of convicted for crime or arrests of other individuals considered as escape suspects. In these are included also the military personnel. Port Police Authorities cannot intervene for crimes committed in foreign warships. But when at these warships resort individuals of interrogative interesting then they require from the foreign war ship master the delivery of them and in case of refusal they refer to the competent Public Prosecutor (Note 31).

As far as concern the Maritime Penal Procedure Law, according to article 240 of COMPL (Note 32) the provisions of HPP are enforced to the prosecution of crime which was committed on a vessel or to a auxiliary docked vessel, provided that they are not modified by the procedural provisions of COMPL namely by the articles 241-244 (Note 33). So investigative tasks for crimes committed on a vessel or on a auxiliary docked vessel and are under the jurisdiction of the Hellenic authorities are enforced by:

A. - Port Police Authorities and the Directorate of Vessels Inspection in Hellas (Note 34).

B. - The consular Authorities and in case of non-existence the master and

C. - the master (Note 35) of the vessel when the crime committed during the voyage and until the arrival into port where is located the Port Police or consular authority.

From the above is concluded that key role for the enforcement of HCG personnel competences at port areas, plays the real in case fact, if the areas are fencing or not, if there is etched or equivalent land port area (Note 36). From the applicable legislation reveals that HCG personnel enforce different judicial and police competencies in any case.

This competencies double character of cause confusion to the HCG executives during the enforcement of their competences because at a part of the port can be responsible for intervention for a specific offence but cannot be responsible for intervention for the same crime at another part of the port.

A typical example is tourism. According to article 40 of the General Port Regulation control (Note 37) "............is prohibited in any way the inconvenience of the travelers in order to attract them and to prefer specific vessel, hotel, etc". The violation of this provision is punishable by a fine in accordance with the procedure predicted in article 157 of COMPL (Note 38).

But at ports which are not fencing according to the provisions of LD 444/70 tourism is not within the HCG competence. Referring helpfully to law 3561/1993 (A' 118) «Settings for tourism and other provisions» and 
especially in paragraph 3 a. reveals that «whoever encourages and harass in any way person or group of persons to accept or reject a travel or shipping service, restaurant services or entertainment or tourist accommodation or trader products, is punishable by imprisonment up to six (6) months or with penalty fine at least one thousand (1000) or with both of these penalties»».

According to the above legal formalities is raising item if whether in a port area without fence which is land area of port or equivalent to a land area HCG personnel has responsibility for this specific item, namely to form penal proceedings folder and to impose the predictable administrative sanctions where is appropriate.

In this specific case must be clarified legislatively the enforcement of this specific competence in the direction of the unified area of the port as happened with the competence of the traffic police, or in the case that this does not happen, to be submitted to the Public Prosecutor of the Hellas Supreme Court or to the State Legal Council request because of its high importance.

In any case after relative order of the public prosecutor is formed penal proceedings folder following the ordinary or the flagrant procedure, but may be subject point of local or and circle item of jurisdiction for the executives that deal with, with criminal but especially urban consequences by the citizen against whom are the criminal and administrative actions.

Of course, the conditions of article 275 of HPP are in force but in the administrative part, have the HCG personnel the authorization to certify infringements and to issue decisions imposing fines? From the legal provisions reveals clearly that the specific competence in specific area of port (not fencing), exclude of HCG competencies.

Problem is the enforcement of HCG duties based on articles 136-145,158-163 and 156-157 of COMPL create the provisions of law 2960/2001 (A' 265) «National Customs Code». More specifically from the provisions of this law in conjunction with the above concerning the enforcement of judicial and administrative police reveals the following:

A. - according to article 5 of this law «as customs precinct are used and the necessary public spaces of ports, airports and railway stations. The limits of the precinct area for each customs authority are established by a decision issued by the head of the customs authority, which is approved by the Minister of Finance, after suggestion of the Head of the competent customs region». Namely is defined as a Customs precinct port areas without planned to be requested the opinion of the MSA.

B. - According to article 3 paragraph 2 of the same law the Customs Office is responsible in customs precinct and generally in the customs territory (Note 39) for matters such as safeguarding of public health and society, control of individuals, baggages, passengers, cargo and vehicles for detecting illicit drugs, weapons, explosives, etc., as also for irregularities relating to transport, fisheries, immigration, environmental protection, etc.. With the above is lifted the general police competence of HCG.

C. - In the same article in paragraph 3 is determined that in the exclusive competence of the customs service is the supervision, control and guarding of the premises have been identified as customs precincts and storehouse of temporary storage or have been approved as free zones.

With reservation of HPP provisions (Note 40) concerning the criminal investigations acts, the entry within these spaces of any other staff member of another public or private enforcement service is allowed on written notice and approval of the head of the competent customs authority.

Further, installation of port output points at entry - exit points as also at customs precincts aims at the law keeping within these spaces and do not provide to the port police authorities personnel the competence of goods, transport, means, warehouses and travelers luggage control (limiting the general policing authority).

D. - With article 147 of the aforementioned law is imposed by the officers of Customs Authority fine of $900 \mathrm{E}$ to anyone who carries passengers or goods via customs precinct and have violated customs or Port legislation.

In this case namely the administrative police which is carried out by HCG with issuing of police regulations in the form of General Regulation Port or Special Regulation Port or any other legislation which is implemented by HCG and imposed administrative sanctions in pursuance of this, becomes Customs authorities competence because as have been mentioned before is needed written notification and written permission of the head of the customs authority in order the HCG personnel to enter in Customs precinct (we always refer in the case that is identified with port or includes a part of it) in order to carry out checks and to impose administrative sanctions. Concomitant competencies that were enforced by the HCG concerning sanctions imposition for port legislation provisions violation become parallel with the competencies which are enforced by the Customs authorities as they can henceforth to impose administrative sanctions for the same legislation. 
Important issue referring to administrative and judicial police duties of $\mathrm{HCG}$ are the measures of regulating road traffic as set out in article 52 of the law 2696/1999 (A' 57), «Ratification of the highway code» as amended and being in force. Specifically, this law repealed the provisions of GPR related to traffic police issues at the ports.

In order to be implemented the provisions of Traffic Highway Code at the ports and taking under consideration the provisions of law 2881/2001 (article 14) according to the traffic police control is exclusive competence of HCG, actions should be taken by each Port Police Authority in its jurisdiction for implementation of defined in the first paragraph of article 52 of this law in conjunction with the defined in article 109 which determines the ways of decisions publication (Note 41).

In case that have not taken actions for implementation of the above mentioned, all the administrative actions of HCG personnel with which certify infringements for fault violations, administrative fines imposition for violations of Highway Code (Traffic Offences) are lack of legitimacy, are characterized as fictitious and bear legal consequences for the personnel that certified them (Note 42).

Finally, reflection concerning the enforcement of HCG competencies create the competencies of the new police institution of Municipality Police as reflected in the provisions of law 3775/2008 (A' 263) (Note 43).

In the provisions of article 1 and more specifically in paragraphs 3 and 4 are reported case by case the competencies that are enforced by the Municipality Police and according to which preconditions by the Hellenic Police (HP). At these cases there is not taken any prediction for HCG which according to its institutional role enforce police competences in areas of its jurisdiction as has been mentioned before.

The fact that there is no any report to the HCG except the cases that are described in paragraphs 8 and 9 of the same article, leads to the conclusion that minor of the specific competencies reported in those paragraphs relating to the High Way Code Traffic, the rest of the competencies and in case by case that are issued or not the regulatory acts predicted in this article, can not be exercisable by the Municipality Police in areas where HCG has competence.

This is confirmed and by the wording of article 2 paragraph 1 of law 3771/2008, where is reported to the contribution of the HP to the staff of the Municipality Police in the performance of its work, without any mention to the HCG. It is clear that the HP competence based on law 2800/2000 is enforced in specific areas in which according to the provisions in force HCG has no competence.

Consequently the issuing of the decision predictive in paragraph 6 , article 1 must be initiated within this framework.

Also important is the competence for interventions at the coast and beach. As reveals from the law, in force, is provided to the HCG personnel the administrative possibility to deal administratively for arbitrary intervention at the above areas imposing in any case the prescribed administrative penalties when is appropriate. For the penal part of the case competent authority is HP.

Although the penal from the administrative part of one case constitute legally different cases, given the particular nature of such cases and in order these cases to be faced totally should be determined only one Police Authority which will be responsible for the initiation of the penal but also of the administrative procedure for offences that are committed at the coast and at the beach (Note 44).

\subsubsection{Merchant Marines Disciplinary Councils (PSEN)}

Significant competence of judicial power enforcement compose the constitution of Merchant Disciplinary Councils by the MSA and the imposition of disciplinary penalties to seafarers with result the deprivation of the possibility to exercise the seaman profession temporarily or even permanently.

In particular, according to article 257 of COMPL the disciplinary power against seamen is being implemented by the master of the vessel, Port Police Authorities and Consular Port Police Authorities while the Disciplinary Councils of Merchant Marines (Note 45) as have been mentioned before impose the penalty of temporary or permanent deprivation of the profession exercise (Note 46).

COMPL in article 245 determines that disciplinary offence is every violation of official duties as well as any other act specifically provided in section of disciplinary provisions in the fifth part. The master and the crew official duties are determined in the vessels work regulations (Note 47).

In article 246 are determined the disciplinary offences of the master while in article 247 are determined the disciplinary offences of the crew. 
For violations of official duties and obligations, namely to those who commit disciplinary offences are imposed disciplinary penalties. According to article 248 of COMPL the disciplinary penalties are the reprimand, fine, temporary deprivation of seafaring profession and the definitive deprivation of seafaring profession.

Disciplinary offences according to article 255 of COMPL are prescribed:

a. - these which are under the responsibility of captain after six months from the perpetration,

b. - these within the jurisdiction of the Consular Port Police Authorities or Port Police Authorities after a year from the perpetration,

c. - these that effect the temporary or permanent deprivation after four years of their perpetration.

In accordance with article 256 of the COMPL the disciplinary sentence which was imposed irrevocable is prescribed after six years since the issue of the relevant decision, out of those requiring permanent deprivation.

\subsubsection{Administrative Investigation of Maritime Accidents (ASNA)}

The Superior Council of Maritime Accidents (ASNA) (Note 48) which is responsible for maritime accidents investigation (Note 49) even due to war cause, established in order due to the specific nature of maritime accidents and the expertise required to investigate them, to help with the executives who consist it to the complete circumstances investigation under which took place a maritime accident (Note 50).

The provisions for the administrative investigation of a maritime accident are determined in the LD 712/70 (A' 237) as amended by article 9, paragraph 10 of law 2575/98 (A' 23). In parallel the administrative investigations of maritime accidents is predicted also in the International Convention for the Safety of Life at Sea (SOLAS 74, regulation 21, Section a, Part c) which was ratified by Hellas with law 1045/1980 (A' 95).

When investigations concerning maritime accidents carried out by Port Police Authorities of by Consultant Port Police Authorities or by HCG officer designated by the Minister of Shipping and Aegean (Note 51) are completed folders of penal proceedings after the end of preliminary investigation are submitted to the MSA without including report of the Authority or of the officer who conducted the preliminary investigation.

The Minister of Shipping and Aegean refer the folder of the penal proceedings to A.S.N.A., which carry out under the supervision of their Presidents, tactical interrogation if the Councils consider that the conducted preliminary investigation was inadequate. Minister of Shipping and Aegean has the opportunity if considers on the basis of a reasoned opinion not to submit the penal proceedings file to ASNA (article 2 paragraph 6 LD 712/70).

If from the preliminary investigation reveals indications of criminal offence performance or has submitted a complaint against any responsible person, the officer who conducted the preliminary investigation if is an officer of HCG and in other cases the MSA transmit the penal proceedings folder containing all the documents with all the information to the competent Public Prosecutor of First Instance Court (article 2, paragraph 7 LD 712/70).

In each case of maritime accident is defined by the President as rapporteur, one of the members of the ASNA, who is studying the case and suggested on this in front of the Council and then ASNA decides with report on the causes, circumstances and responsible persons of the accident and the degree of responsibility, unanimously or by majority vote (in the event of tie the President shall have the casting vote).

The procedures in front of ASNA must be completed within the time limits which are determined by the LD 712/70, which must not exceed a total of seven (7) months from delivery of the maritime accidents penal proceedings folder to ASNA.

In practice, usually these deadlines are respected, except in certain exceptional cases in which should be conducted by the Councils tactical interrogation and deadlines cannot be kept (call witnesses, receiving testimony, correspondence with authorities, organizations, agencies, individuals, etc.).

ASNA report with the maritime accident penal proceedings folder is submitted by the President to the Minister of Shipping and Aegean (Note 52) but in practice the completed cases are sent to Safety Navigation Division (DAN) which then send report copies as well as the regular penal proceeding folders to the competent Public Prosecutors, in order to evaluate the gathering preliminary investigation material. If reveals elements of master disciplinary responsibility of Masters or crew members these reports are also submitted and to the Competent Disciplinary Council of Maritime Merchant (PSEN) for the imposition of disciplinary sanctions (article 6 LD 712/70).

ASNA reports do not bind judges and are evaluated by them freely along with other evidences of affairs. However in practice all the Public Prosecutors Authorities in Hellas before proceeding in criminal prosecutions on maritime accidents, awaiting Councils reports which study - consult, because of the fact that in ASNA are involved specialized individuals who have special knowledge and experience in maritime accidents. 
It must be mentioned that is notable the fact that in this LD the Minister of Shipping and Aegean ordered after reporting of the Consular Port Police Authority or of the Port Police Authority if considers that aids reason for further investigation the conducting of preliminary investigation as also the Port Police Authority which will carry out this. This is according my personal view interference of the Executive in the Judiciary Power which reverses fully the distinction of the functions that are predicted in the Constitution.

Further is provided to the Minister of Shipping and Aegean the opportunity with reasoned discretion not to refer the penal proceeding folder to ASNA. In this case without defined something relevant to the provisions of LD is concluded the conclusion that the Minister of Shipping and Aegean if will not the penal proceeding folder to ASNA, obviously the folder will not be forwarded to the competent Public Prosecutor at First Instance either.

Further if from the preliminary investigation reveal indications of criminal performance offences or has been submitted a complaint then the HCG officer if he/she conducts the preliminary investigation or the MSA transmit the penal proceeding folder with the documents to the competent Public Prosecutor at First Instance.

In article 5, paragraph 5 is determined that the Minister of Shipping and Aegean in serious and urgent cases automatically or after an application submission of anyone who has legitimately interest can order directly under the ASNA the conducting of tactical interrogation if is not carried out a preliminary investigation by the Port Police Authorities or Consular Port Police Authorities and the one which have been started will stop.

I believe that the above mentioned provisions beyond the judiciary jurisdiction which is provided to the Minister of Shipping and Aegean which as has already mentioned violates the powers separation, clearly come in stark contrast with the provisions of the existing HPP in which are defined the duties and obligations of Public Prosecutors and of officers who conduct preliminary investigations.

In particular, the provisions of LD 712/70 described above are coming into direct conflict with the articles 27 «Criminal prosecution performance», 28 «Independence of the authority performing the prosecution», article 31 «Prosecutor rights», article 33 «General police investigators», article 36 «Ex officio prosecution», article 37 «Obligation criminal action announcement», article 43 «Initiation of criminal proceedings» article 44 «Postponement and suspension of prosecution» of HPP.

Also for accidents investigations are enforced the provisions of law 3877/2011 (A' 264). The investigations which are carried out according to the provisions of this law are not related to determining fault or accountability and are independent of the investigation process provided in LD 712/1970 (A' 237) (Note 53).

\section{Hellenic Coast Guard Aiding Mission}

Civil protection aims to the life, health and property protection of citizens from natural (rapid or slow evolution), technology (including biological, chemical and nuclear incidents) and other disasters, which cause emergency situations during a peaceful period. Within the same purpose is the care for material and cultural goods, the wealth resources and infrastructure of the country, with view the minimizing of disasters consequences (Note 37).

The participation of HCG in the separate actions of civil protection (Note 55) for combating disasters and emergencies is provided in the article 3 paragraph 1b, of law 3013/2002.

At the same time according to article 33 of the PD 67/201,1 at HCG Headquarters have been established the Civil Defense - Civil Emergency Planning - State Maritime Transports Division which is consisted by the following departments:

A. - Civil planning.

B. - NATO planning.

C. - Requisition and charter.

D. - Civil defense (Note 56) and

E. - Management of Navy requisitioned Fixed Advanced.

The functions of this Division are determined by the special provisions of article 15 of LD 17/1974 concerning «Civil Emergency Planning» (A' 236), of PD 941/1980 «Organization and function of Ministry of Mercantile Marine Civil Defense Division - Civil Emergency planning» (A' 237), law 569/1995 «Civil Protection» (A' 212) in part which is still in force, law 2641/1998 «Universal Defense» (A' 211) (Note 57) and the National Mail Rules (EKA) which was ratified by the decision with No EФ 120/6/200994 $\Sigma$. 1691 issued on June 08,2004 by the Minister of National Defense and the Compulsory Law (CL) 2006/1939 [«Amending and supplementing of law 4874/29 «on military contributions and charted» (A' 430)] (Note 58). 
Former Ministry of Mercantile Marine, the Aegean and Island Policy (MMMAIP-YENANP) (now MSA) according to the MD with No 1299 issued on April 04, 2003 issued by the Minister of Interior (B' 423) and subject [Approval of the civil protection general plan under the password word «Xenocratis» issued on April 7, 2003] has drafted and forwarded to the Ministry of the Interior Special Projects according to its competencies which are determined in the relevant provisions of the above mentioned plan.

At the same time evaluate risks from natural-technological and other disasters which threat parts of Hellas, on the basis of its local and given circle of items competence. Identifies the objectives of dangerous phenomena in specific cases and formulate the required strategy for the objective success and tactics for the strategy implementation.

In particular the MSA is doing the following:

a. - plans within their competence and on the basis of the «Xenokratis» plan measures to combat natural, technological and other disasters (Note 59),

b. - sends the draft prepared document to the Civil Protection General Secretariat for approval,

c. - mobilizes the central and regional services and provides the necessary means for combating marine pollution, dealing with accidents and other disasters as also conducting search and rescue operations in the area of its competence (Note 60),

d. - cooperates with relevant State departments for combating radiological, biological, chemical and nuclear threats in the field of its competence,

e. - ensuring the necessary floating means when is required by exceptional needs for transporting personnel and supplies and

f. - acts any other than according the circumstances, its mission and the legislation in force is/are imposed (Note 61).

Also the MSA according to the decision with No 3384/2006 (B' 776) [ «Complementary of the general Civil Protection plan under the password word «XENOKRATIS» with the special project «Human Losses Management»] participated in the preparation of the appropriate projects mentioned in the management of human losses.

Provisions of the HCG legislation determine the specific status of certain services that are contributed defining in the fulfillment of its role as an executive mechanism, participating in all the civil protection actions as the Air Transport Service and the Unit of Special Forces (Note 62).

HCG is participating in all the responsible institutions according its competences provided by the provisions of law 3013/2002 (Note 63) as amended (Note 64) by the law 3613/2007 (A' 263) and in particular with article 18 (Note $65)$.

Finally in the auxiliary mission of HCG are included the gathering of port and beacons fees, pilot rights and the exercise of Port Police Authorities duties in Seaman House (ON) which all of them should be reconsidered if they must carried out by HCG, because in any case the exercise of those powers has a revenue character and refers to the rights of other public legal persons, which should carried out these competencies (Note 66).

\section{Conclusions}

HCG and more specifically the critical approach of provisions that determine the competencies which govern the activities of executives in the area of public order and security and in particular of the provisions that define the activation working framework of HCG personnel, both in the performance of Judicial and Administrative Police duties were the subject of this concise summary study.

HCG activation is divided into main and auxiliary. The first refers to safeguard and to maintain of public order and to the protection of public and state security. It covers three main competencies cycles: Firstly the safeguard of public peace and order and the smooth social life of citizens (general police policing).

Secondly to the prevention and repression of crime (public security police) and thirdly, State and democracy regime protection within the framework of the constitutional order (State security police).

In the HCG mission additionally to the mentioned police competencies and duties, belong also and competencies duties concerning maritime policy. For the implementation of legislation concerning the safety of Hellenic vessels and crews as also the settlement of disputes have been established Port Police Authorities at the foreigner, aiming to support and to facilitate the Hellenic shipping. 
HCG personnel police competencies are subjected to the administrative law principles and in particular to the principles of legality, of public interest primacy, of proportionality, of non-discrimination and equality. In addition the HCG invasive actions because often intervene in citizens basic goods and freedoms are governed by certain principles of the public law order. They are the principles of continuous preparedness and continuous sustainable service, action, the prohibition of process abuse and the respect for innocence presumption.

The subsidiary mission is composed to the participation of HCG in combating to any emergency reveals from natural phenomena or other disasters in a period of peace or war in cooperation with the relevant Authorities and services as also in ensuring of national defense in cooperation with the armed forces.

Important is also the HCG mission on search and rescue items in the area of the Aegean Sea, taking into consideration the dispute of Hellas sovereign rights from Turkey in this area. To HCG has been assigned institutionally via the Hellenic Joint Rescue Coordination Center (JRCC-EKSED) the coordination of means in order to be ensured the protection of human life (search and rescue) where is necessary in maritime area which constitutes F.I.R. Athens.

HCG personnel duties are described in the law. For the protection of individual rights and liberties, HCG executives are obliged in any case to make good use of the discretion, which is necessary for getting any proper police measure. If they enforce judicial competences, the competence in this case is bided and is governed by the provisions of HPP.

It is also necessary the reorienting of the existing institutional framework for the enforcement of powers at the port area. In particular the dual nature of the competences which are enforced at ports and the different institutional framework specified in fencing and not fencing ports must change in the direction that at the area of the port must be enforced all the competences pertaining to the policing at fencing port without exception.

In that way the HCG personnel will be assisted in the performance of their duties, without creating problems every time concerning the defining of the territorial and the competencies which must be enforced each time.

HCG must be disengagement from tasks which are not within the circle of its competencies, such as the control and revenue of port and bacon fees, the performance of Retired Maritime Fund (NAT) and Seaman House (ON) and their executives to focus on the police duties and tasks enforcement as also to the enforcement of duties to support the Hellenic shipping.

Finally the tasks concerning port, beacons and pilot fees revenue, the enforcement of duties of Retired Maritime Fund (NAT) as also of the Seaman House (ON) which have characterized as revenue duties must be enforced by legal persons to which have been assigned the appropriate competence.

\section{References}

Anagnostopoulos, I., \& Vathiotis, K. (1999). Penal Code. Athens: P. Sakkoulas (in Hellenic).

Code of Maritime Law as is in effect today (1988). Publication issued by the Ministry of Mercantile Marine. Athens (in Hellenic).

Dagtogloy, P. (1997). General administrative law. Athens-Komotini, Sakkoulas (in Hellenic).

Korontzis, Tr. (2006). The enforcement of administrative police by the Hellenic Coast Guard. The institution process of the procedure for sanctions enforcement concerning the violation of Ports General Regulations. Statistic elaboration of Piraeus Port Police Authority facilitation in the period 1993-2001. Nautiki Epitheorisi, 557, 87-118 (in Hellenic).

Korontzis, Tr. (2009a). Administrative governmental reforms. The case of Ministry of Mercantile Marine, the Aegean and Island Policy (MMMAIP-YENANP), Dioikitiki Enimerosi (quarterly journal of administrative inspection), 52, 31-57 (in Hellenic).

Korontzis, Tr. (2009b). Protection of maritime environment: The role of Hellenic Coast Guard, Dioikitiki Enimerosi (quarterly journal of administrative inspection), 51, 77-90 (in Hellenic).

Korontzis, Tr. (2009c). Disciplinary, obligations and limitations of employees in the area of public order and security, Epitheorisi Ergasiakon Sxeseon (quarterly Inspection of Labour Relations), 55, 75-96 (in Hellenic).

Korontzis, Tr. (2010).Coast Guard and administrative experiments. Dimosios Tomeas, 269, 33-35 (in Hellenic).

Korontzis, Tr. (2011a). Security and ports. The contribution of ISPS Code in combating illicit actions», Nautiki Epitheorisi, 578, 65-81 (in Hellenic). 
Korontzis, Tr. (2011b). The stationary role of Hellenic Coast Guard. PhD dissertation, Public Administration Department, Law Sector, library of Panteion University of Social and Political Sciences, Athens (in Hellenic).

Korontzis, Tr. (2012a). The prohibition of vessels departure for reasons concerning the ensuring of public and private interests in the Hellenic legal order. International Journal of Humanities and Social Science, 2(5), 704-719.

Korontzis, Tr. (2012b). The competence of Hellas on search and rescue items in the Aegean area. Review of European Studies, 4(2), 89-110.

Korontzis, Tr. (2012c). Civil protection administration systems in Hellas. Dioikitiki Enimerosi (quarterly journal of administration inspection), 61, 85-105 (in Hellenic).

Korontzis, Tr. (2012d).The prohibition of vessels departure for safety navigation reasons in the Hellenic legal order. International Journal of Asian Social Science, 2(5), 704-719.

Korontzis, Tr. (2012e). Penal, disciplinary and civil responsibility of the Hellenic Coast Guard personnel. International Journal of Humanities and Social Science, 2(9), 174-185.

Korontzis, Tr. (2012f).The role of the Hellenic Coast Guard in the Hellenic internal security and in combating the phenomenon of organized crime. International Review of Social Sciences and Humanities, 3(1), 210-227.

Korontzis, Tr. (2012g).The Hellenic Ministry of Mercantile Marine, as an autonomous administrative governmental institution in the period 1971-2011. A descriptive and critical approach. International Journal of Business and Social Science, 3(8), 61-75.

Korontzis, Tr. (2012k).The prosecution of economic crime in Hellas. International Journal of Humanities and Social Science, 2(5), 221-227.

Korontzis, Tr. (20121). The establishment of judicial police as an administrative reform. An evaluation approach. Dioikitiki Enimerosi (quarterly journal of administration inspection), 57, 76-93 (in Hellenic).

Korontzis, Tr. (2012m).The contribution of EUROPOL and FRONTEX in combating the phenomenon of illegal immigration in Hellas. Review of European Studies, 4(1), 188-202.

Korsos, D. (1995). Administrative law, General Part. Athens-Komotini: Ant. Sakkoulas (in Hellenic).

Lytras, S. (1986). The concept of administrative fines and the constitutionality of their enforcement. Athens Komotini: Ant. Sakkoulas (in Hellenic).

Lytras, S. (1993). The Organization of public administration, Legal approach. Athens - Komotini: Ant. Sakkoulas (in Hellenic).

Papahatzis, G. (1991). The current system of administrative law in Hellas (7th ed). Athens (in Hellenic).

Papaioannou, Z. (2006). Police Law. Athens-Komotini: Ant. Sakkoulas (in Hellenic).

Stamatis, K. (1972). Police Law. Athens (in Hellenic).

Stasinopoulos, M. (1976). Administrative law courses. Athens (in Hellenic).

Tachos, A. (1990). Law of public order. Thessaloniki: Sakkoulas (in Hellenic).

\section{Notes}

Note 1. See article 4, paragraph 1, of law 3922/2011 (A' 215) and article 5, paragraph 1 of law 2287/1995 (A' 20).

Note 2. According to the paragraph 1 of law 3922/2011 was allowed the secondment of HCG personnel for the exercise of competences which had been placed according to paragraph 1 of article 2 of PD 127/2010 (A' 214) at the Ministry of Maritime Affairs, Islands and Fishing (MMMAIP-YENAP). The last one according to article 4 of PD 65/2011 (A' 147) merged with the Ministry of Economy, Competitiveness and Shipping in the new Ministry entitled Ministry of Development, Competitiveness and Shipping. Following with the PD 94/2012 (A' 149) was reestablished the MSA in which returned the HCG. See also, Korontzis, Tr. (2012g). The Hellenic Ministry of Mercantile Marine, as an autonomous administrative governmental institution in the period 1971-2011. A descriptive and critical approach. International Journal of Business and Social Science Vol. 3, issue 8, p.p.61-75.

Note 3. See article 46 of PD 67/2011 (A' 149). Additionally their duties are determined by the MD with No 1141.1/39/02 (B' 929) and 1141.1/11/2005 (B' 729) respectively. 
For the same subject relative is the opinion with No 48/1992 issued by the Council of the State according to is legally possible the conducting of preliminary investigation by the Consular Port Police Authorities of preliminary investigation concerning declared accidents occurring in Hellenic seamen who work as crew on ships with a foreign flag but who are not contracting with the Retired Maritime Fund (N.A.T.).

Note 4. See op.cit. note 1 and additionally Korontzis, Tr. (2009c). Disciplinary, obligations and limitations of employees in the area of public order and security, Epitheorisi Ergasiakon Sxeseon (quarterly Inspection of Labour Relations), issue 55, p.p. 75-96 (in Hellenic)and Korontzis, Tr. (2012e). Penal, disciplinary and civil responsibility of the Hellenic Coast Guard personnel. International Journal of Humanities and Social Science, Vol. 2, issue 9, p.p.174-185.

Note 5. See Korontzis, Tr. (20121). The establishment of judicial police as an administrative reform. An evaluation approach. Dioikitiki Enimerosi (quarterly journal of administration inspection), issue 57, p.p. 76-93 (in Hellenic).

Note 6. See Korontzis, Tr. (2012f). The role of the Hellenic Coast Guard in the Hellenic internal security and in combating the phenomenon of organized crime. International Review of Social Sciences and Humanities, Vol. 3, issue 1, p.p. 210-227 and Korontzis, Tr. (2012k).The prosecution of economic crime in Hellas. International Journal of Humanities and Social Science, Vol. 2, No. 5, p.p. 221-227.

Note 7. See Korontzis, Tr. (2012b). The competence of Hellas on search and rescue items in the Aegean area. Review of European Studies, Vol. 4, issue 2, p.p. 89-110.

Note 8. See Korontzis, Tr. (2009b). Protection of maritime environment, The role of Hellenic Coast Guard. Dioikitiki Enimerosi (quarterly journal of administrative inspection), issue 51, p.p. 77-90 (in Hellenic).

Note 9. See Korontzis, Tr. (2012m). The contribution of EUROPOL and FRONTEX in combating the phenomenon of illegal immigration in Hellas. Review of European Studies, Vol. 4, issue 1, p.p. 188-202.

Note 10. See Korontzis, Tr. (2011a). Security and ports. The contribution of ISPS Code in combating illicit actions. Nautiki Epitheorisi, issue 578, p.p. 65-81 (in Hellenic).

Note 11. In article 1 of the law 2571/2001 is determined that: «Port is a land and sea zone together with equipment and work, permitting basically the reception of all kinds of vessels and recreational vessels, loading and uploading cargo, storage, receipt and forwarding of cargoes, servicing passengers and vehicles and the development of business activities, linked directly or indirectly with maritime transport».

On the same law relative are also the articles 18 «Port zone», 19 «Port land zone» 20 «Port sea zone», 21 «Determination of land and sea port zone» and 22 «Status of port area land zone» of law 2571/2001 as amended and being in force with law 3153/2003.

To the above must be added and the provisions of LD 444/70, law 2356/1994 (A' 162), article 12 of law 2289/1995 (A' 1995) and articles 136-140 of LD 187/1973 (A' 261).

According to article 19, paragraph 5, of law 2571/2001 «is allowed with expenses of the competent administration and exploitation institution of the port the fencing of a part or of whole of the land zone of the port. The parts that are fenced and the way of fencing are determined by decision of the Secretary-General of the region after a proposal issued by the administration and exploitation agency of the port or issued by the Port Police Authority with the approval of Architectural Control Committee (EPAE) and agreed opinion of General Navy Staff (GEN) and the Ministry of Mercantile Marine. These opinions are provided within three (3) months of receipt by the GEN and the Ministry of Mercantile Marine of the relative document».

On the same subject has been issued and the No 80/1997 Opinion issued by the Council of State according to, the fact that a decision has been taken by the responsible authority for fencing a zone part of the port, is not enough in order to be characterized this part as a fence area of the port within the meaning of the paragraph 1 of article 3 of the LD 444/70, but is required for that purpose and the implementation of fencing.

Note 12. See Anagnostopoulos, I.,Vathiotis, K (1999). Penal Code, Athens, Sakkoulas, p. 2.

«Crimes which are committed in domestic»

Article 5.-1. The Hellenic Penal Laws are enforced to all offences which were committed in the land of the territory, even from foreigners.

2. Ships or aircraft are considered as Hellenic territory wherever situated, unless according to an international law are subjected to a foreign law. 
Also see Korontzis, Tr. (2011b). PhD dissertation titled «The stationary role of Hellenic Coast Guard»,[Public Administration Department, Law Sector], library of Panteion University of Social and Political Sciences, Athens, p.p. 215-255 (in Hellenic).

Note 13. The functioning of the Port Police Authorities as has already mentioned, is determined according to the decision with No 1220.3/01/2001 issued on April 10, 2001 as was supplemented subsequently by the decision with No 1220.3/10/2004 issued on April 21, 2004 according to which established Port Administration Center. It is implemented at the Port Police Authorities (Central Port police authorities, Port Police Authorities, Sub Port Police Authorities) and regulates the organization, structure, competences and the way of function of these services. See also and article 45 of the PD 67/2011 (A' 149).

Port Police Authorities are public authorities. As public authorities are meant the institutions of the State empowered by law to issue enforceable administrative acts, they have the so-called strong powers as it has been known. The term «public authority» is reached and as administrative authority with the same conceptual content. See Stasinopoulos, M. (1976). Lessons in administrative law. Athens, p. 275.

Note 14. In the same provision was determined that the fines for illegal parking restrictions imposed by Port Police Authorities in the implementation of High Way Code (Traffic Offences) constitute revenue of Port Authorities or Port Funds, which have the use and exploitation of these areas and are collected in accordance with the provisions of Code of Public Income Collection (COPIC).

From the provisions of this law is becoming clear the police role of HCG and the visibility of the roles with the other main mechanism of general policing in Hellas the HP.

Note 15. Public police is divided into judicial and administrative police.

Judicial police is enforced by a category of police executives, who have as mission, the assistance to the judicial authorities for criminal justice awarding (detection, arrest and delivery of perpetrators for illegal acts). Its action is specified in the provisions of HPP.

Administrative police is activating outside of criminal justice sphere of the State. It exercises basically preventive work aiming on ensuring public order and prevention of crime, often through police intervention and imposition of restrictions on personal freedoms and rights. Administrative police is different from the security police which is enforced with further purpose the population and law order protection from unlawful acts. This distinction is important because is delimited the control between penal and administrative judge. The above discrimination is not entirely clear in Hellas. This because are crossing the judicial competences with the administrative competencies. Many times are found executives who exercise police competences to carry out competencies of judicial police or in other cases executives who exercise administrative police duties to carry out duties of police order [e.g. Customs officials, Public Tax Offices employees etc., enforce duties of judicial police as special police investigators officers (articles 27, paragraph 2 and 3, 34 of HPP)], see Papaioannou, Z., (2006). Police Law, Athens-Komotini, Ant. Sakkoulas, p.p. 4-7 (in Hellenic) and Tachos, A. (1990). Law of public order. Thessaloniki, Sakkoulas, p. 58 and next (in Hellenic).

Note 16. Legislator with the specific determination of competence is attempting to protect the public interest and to avoid the accumulation of many cases in the same person.

A body (executive) is characterized that has a general police competence when is authorized by the law to manage legitimately all the displayed issues within its local competence of jurisdiction without to be permitted the executives intervention of other police authority except in the cases which specifically are regulated in the law.

A body (executive) is characterized that has a special police competence when is authorized by the law to manage a certain subject or number of issues within the local jurisdiction, excluding further expansion.

From the above reveal that exists:

- General police competence for a given circle of items and

- Special police competence for a given circle of items.

With the local jurisdiction are regulated the limits of the areas between executives of different police services who are subjected to different police corps or authorities.

The reasons which impose police competence are:

1.-The need of bodies (executives) action within a specific area,

2.-State distinction in regions and their check by the competent police authorities/services, 
3.-the existence of different police services for performing the various tasks which have been assigned to them by the State and

4.-the obligation of the police services to be limited in specific areas in order to enforce their duties. See Stamatis, K. (1972). Police law. Athens, 1972, p.p. $35-44$ (in Hellenic) and Tachos. A., ibid., p. 48 and next (in Hellenic).

Note 17. See law 3922/2011 (A'35).

Note 18. See Korontzis, Tr. (2006). The enforcement of administrative police by the Hellenic Coast Guard. The institution process of the procedure for sanctions enforcement concerning the violation of Ports General Regulations. Statistic elaboration of Piraeus Port Police Authority facilitation in the period 1993-2001. Nautiki Epitheorisi, issue 557, p.p.87-118 (in Hellenic).

Additional relevant are the articles 458 and 459 of HPC. For the implementation of article 458 is necessary the special provision of the administrative law to report that the violation of this is punishable under article 458 of HPC with a fine. According to article 459 the offender should violate police provision which concerns object or purpose other than those referred in articles 413-457 and is punishable by a fine or detention. For the establishment of criminality action is required the existence of a valid police provision.

It should be noted that the violation of police regulations issued after authorization of the law are subjected to the penalties provided by law which grants the authorization. Faults infringements exist beyond the HPC and in police provisions which are issued after relative legal authorization as also in numerous other special penal laws, such as laws relating to relevant offences e.g. with vehicles [see law 2696/1999 (A' 57) «Ratification of the highway code», as amended by the law 2898/2001 (A' 71), law 2963/2001 (A' 268), law 3082/2002 (A' 316), law 3212/2003 (A' 308), law 3153/2003 (A' 153), law 3254/2004 (A' 137), law 3399/2005 (A' 255), law 3446/2006 (A' 49), law 3534/2007 (A' 40), law 3542/2007 (A' 50), law 2840/01 (A' 16), law 3463/2006 (A' 114)] etc. For the meaning of fine see Lytras, S. (1986). The concept of administrative fines and the Constitutionality of their enforcement.Athens - Komotini, Ant. Sakkoulas, p. 34 and next (in Hellenic)and Korontzis, Tr. (2011b). The statutory role of Hellenic Coast Guard. op.cit., p.p. 102-119, 122-129 (in Hellenic).

Note 19. In Hellas the main ports are public and procedures, regulations and ground are State's responsibility. See analytically Korontzis, Tr. (2011a). Security and ports. The contribution of ISPS Code in combating of illicit actions, op.cit. (in Hellenic).

Note 20. Concerning Piraeus and Thessaloniki Port Authorities see analytically Korontzis, Tr. (2011), ibid (in Hellenic).

Note 21. Hellas has ratified the International Convention on the International Regulations for Preventing Collisions at Sea by the law 93/1974 (A'293).

Note 22. Relevant for this specific topic is law 2881/01 (A 16) «Regulating issues for lifting wrecks and other provisions» and the following MD which were issued after its authorization with No 2123/36/2001 (B' 1438), No 2123/37/2001 (B' 1438), No 2123/35/01 (B' 1438), No 2123/38/2001 (B' 1439), No 2123/34/2001 (B'1439).

Note 23. See Code of Maritime Law as is in effect today (1988). Publication issued by the Ministry of Mercantile Marine. Athens, article 147.

Note 24. Relevant is the PD 280/2002 (A' 232), titled «Obligation of guardians hired in vessels that are under departure prohibition because of obligatory or conservative seizure after provisional order issued by courts and other necessary with this subject detail».

Note 25. See law 2932/2001 (A'145) as have been amended and been in force with law 3490/2006 (A' 206) and law 3528/2007 (A' 122). Also see Korontzis, Tr. (2012a). The prohibition of vessels departure for safety navigation reasons in the Hellenic legal order. International Journal of Asian Social Science, vol. 2, issue 5, p.p. $704-719$ and Korontzis, Tr. (2012d). The prohibition of vessels departure for reasons concerning the ensuring of public and private interests in the Hellenic legal order. International Journal of Humanities and Social Science, vol. 2, issue 11, p.p. 183-191.

Note 26. See article 156 of LD 187/73 (A' 261) as have been ratified by the law 1940/1991 (A' 140).

Note 27. See article 159 of LD 187/73, 37 and 275 of HPP. It is very clear according to my view that HCG personnel is on ordered service as is defined in the PD 68/2003 (A' 71).

This reasoning is confirmed by the article 10 of the MD with No 1141.1/42/2002 (B' 1122) in which is defined when death, injury or condition of HCG personnel took place during the service, because of service or during execution of ordered service. 
In each case that is necessary the intervention of HCG personnel according to the provisions of HPP, HCG personnel have direct obligation to intervene.

As far as concern article 159 of COMPL [as have been amended by paragraph 2 of article 27 of the law 4033/2011 (A' 264)] is not in contradiction with the provisions of HPP as in the above mentioned article are explicitly included and HCG personnel as general police investigators officers conducting preliminary investigations. Furthermore according to article 594 of HPP are in force the provisions of the CL of October 10, 1935 according to the Harbor Masters are surrounded with power of general police investigator officers for conducting preliminary investigations on crimes taking place in their region competence.

Article 159 of COMPL is not referred to HCG personnel with ranks of First, Second, Third Petty Officers as also to the Port Guards. According to my personal view although these rank are not reported, according to the provisions of HPP can carry out tasks of general police investigators officers for conducting preliminary investigations taken under consideration articles 33-148-152 of HPP in conjunction with article 275 of the HPC.

Note 28. See articles 31, 33 and 43 of HPP.

Note 29. Interventions of a local police authority in other area under jurisdiction of different police authority are permitted in the following two cases:

- in case of flagrant crime and in the absence of the competent police body (executive) whenever the competent police body (executive) who is there is obliged to deal with incident, to arrest the offender, to collect the evidence and to deliver them to the first body (executive) of the local competent authority that will come. If does not appear this body all the above are delivered to the closest competent local police authority.

- in case that any competent police body (executive) who has legally been deled for an offence committed within the jurisdiction of its local region continues persecuting of suspect individual, or surveillance of suspect individuals or of individual who has violated the law in jurisdiction area of a different police authority. The last one since has been invited to assist the pursuit or surveillance has the obligation to assist leaving to the body that originally ruled the whole initiative.

Relative are the provisions of LD 444/70, article 275 of the HPP as well as more specific provisions of laws that regulate each time similar issues of cooperation between security forces, public services, etc. as Custom Office, Finance and Economic Crime Unit (SDOE) etc.

Note 30. See article 127 of law 3079/2002 (A' 311), article 140 of law 187/73 (A' 261) and Royal Decree (RD) 215/1973 (A' 65).

As regards the region of Port Police Authorities jurisdiction in article 2, paragraph 2 of the regulation titled «Port Police Authorities Regulation» which was ratified by the MD of MMMTAIP (Y.E.N.A.N.P) with No 1220.3/01/01 issued on April 04, 2001, is determined that «the jurisdiction region of each Central Port Police Authority, Port Police Authority, Sub Port Police Authority includes ports and bays with the legally land area and the coast generally with the relative territorial sea, continental shelf and Exclusive Economic Zone (EEZ) as these areas are determined by the relevant provisions». This definition is wider of the definition in article 45 of the PD 67/2011 ( $\mathrm{A}^{\prime}$ 149) as is mentioned in the continental shelf and EEZ which have not been set by Hellas.

Note 31. See Korontzis, Tr. (2011). The statutory role of Hellenic Coast Guard, op.cit. (in Hellenic)

Note 32. See Code of Maritime Law as is in effect today (1988), op.cit., p. 128, article 240 titled «Implementation of Penal Procedure Provisions» in which is determined that "during crime prosecution committed on vessel or auxiliary docked vessel are enforced the provisions of the penal procedure code, unless amended by the provisions of the following articles" (in Hellenic).

Note 33. Articles 241 to 244 have the following titles: preliminary investigation duties implementation (article 241), accused pre-trial detention (article 242), submission of penal proceedings files (article 243) and dispatched of judgments against seafarers to the Ministry (article 244).

Note 34. For the Directorate of Commercial Vessels Inspection and the amendments that have been made see paragraph 9, article 23 of law 3922/2011 (A' 35), article 30 of the PD 67/2011 (A' 149) and PD 94/2012 (A' 149).

Note 35. Master during the enforcement of his/her general police investigators duties concerning the conducting of preliminary investigation is hiring as secretary officer of the vessel and if there is any other crew member. If the master participated in crime committed on board cannot carry out a preliminary investigation. 
For crimes committed on a Hellenic vessel during the voyage or to a foreign port the Authority that is handled the situation (conducting preliminary investigation) or the master can order pre-trial detention of the accused in the vessel, in those cases provided by the provisions of HPP with the precondition that the vessel will arrive at a port soon. Concerning pre-trial detention is taking place entry in the logbook.

If the vessel is not going to arrive expeditiously in Hellenic port the Consular take cares to be extended to the shore the pre-trial detention of the accused and at the same time takes the necessary measures for faster transfer in Hellas with a warship which is obliged to accept.

The master of the vessel carrying the accused may during the voyage in accordance with the judgment and his/her own responsibility to order the temporary suspension of preventive detention. The penal proceedings file that formed from the preliminary investigation shall be given in a sealed envelope to the master of the ship carrying the accused in Hellas and delivered together with the accused to the Port Police Authority of the first arrival port. The Port Police Authority sends the accused with the penal proceedings file to the Public Prosecutor (articles 241-244 of COMPL).

Note 36. See note 11 and article 14 of law 2897/2001.

Note 37. In article 1 of the General Regulation Port (A' 393/1978) is defined that [this "General" Port Regulation ........ is enforced to its land and sea zone, ports, bays, as well as in the maritime area of the Port Police Authority jurisdiction and in the area of the existing Port Police Stations and Port Officials, as is determined by the relevant provisions].

Note 38. See note 18 .

Note 39. According to article 1 of law 2960/2001 (A' 265), «country customs territory includes the continental, terrestrial and insular part, territorial waters, internal waters, the internal maritime waters and the airspace».

Note 40. In this specific case must be meant either when is committed an flagrant offence, or when are conducting preliminary investigations actions of other police authority after relevant mandates of Judicial or Prosecutor Authority.

Note 41. In order to be formed completely the relevant penal proceeding folders in cases of traffic accidents but also to be legal the certification of offences with fault character, as also the enforcement of administrative sanctions and administrative measures as provided by the Highway Code (Traffic Offences). It must be noted that after being in force latest special provision as Highway Code other provisions relating to matters such as the General Regulation Port are automatically considered as abolished. In this direction, namely the implementation of traffic regulations at port zones relative is article 23 of law 4058/2012 (A' 63).

Note 42. See Papahatzis, G. (1991). The current system of administrative law in Hellas, seventh edition. Athens, $\mathrm{p}$. 656, p. 743, p.p. 758-759 (in Hellenic), Korsos D. (1995). Administrative law, General Part, Athens-Komotini, Ant. Sakkoulas, p.p. 370-395 (in Hellenic), Dagtogloy, P. (1997), General administrative law, Athens-Komotini, Sakkoulas p.p. 449 and next (in Hellenic) and Lytras, S (1993). The Organization of public administration, Legal approach. Athens - Komotini, Ant. Sakkoulas, p. 74 and next (in Hellenic).

Note 43. According to the explanatory statement of this law and in particular, in paragraph $(\mathrm{F})$, with the law $3643 / 2006$ was rendered systematically and was grouped for first time the extent of the powers of Municipalities and Communities with result the role of local self-government to be upgraded and become more meaningful. This led to the institutional upgrading of Municipality Police because the enlargement of local affairs led to the expansion of local affairs and consequently to the extension of its competencies. It was created with that way a presumption of competence in favor of Municipality Police for controlling the implementation of the regulations relating to local affairs.

Still in the report is predicted that «"policing" implementation by the Municipality Police does not crack in the system of country policing since Municipality Police did not undertake the exercise of all the police competencies in its administrative region limits, but act in a complementary manner and in full accordance with the administration of local cases».

Further and in the analysis of article 1 competences is determined that «are competencies that clearly belong to the Organizations of Local Government (OTA) and stem from the provisions of articles 75 and 79 of Municipalities and Communities Code (law 3643/2006)».

Note 44. Port Police Authority is dealing with offences that have taken place in the region of beach, ashore, sea, land and port zone and simulated areas. 
For the specific item relatives are also except law 2571/2001 as was amended and being in force and the following provisions: law 444/70 (A'39), article 3, paragraph 23, law 2242/94 (A' 162), article 157 of LD 187/1973 (A' 261) as amended and being in force, law 2765/1999 (A ' 97) as amended by the law 3659/2008 (A' 77), law 2690/1999 (A' 45) as amended and being in force by the law 3242/2004 (A' 102), article 276 of the Port General Regulation (B' 378/1978), Joint Ministerial Decision (JMD) with No 1090652/6799/B0010 issued on September 21, 2005, MD with No 5221.1/01/05 (B' 323) and the provisions of the Port General Regulation.

Note 45. The Councils are distinguished in the First Instance Disciplinary Council and Second Disciplinary Instance Council. At the Second Instance Council are submitted the appeals against the decisions of the First Instance. The appeal must be submitted within one month of the decision noticed to the person concerned.

Note 46. See PD 861/1979 (A'246), PD 579/1989 (A’246) and PD 580/1984 (A'206).

Concerning the disciplinary provisions of COMPL relatives are the following legal opinions:

A-Opinion of Council of State with No 276 issued on April 6, 1987 which was accepted by the Minister of Mercantile Marine Decision with no 1481/Ф. 13/87 issued on May 5, 1987 according to is regulated the item of the reference in PSEN for disciplinary offences committed by seafarers and provided in COMPL who are retired by Retired Maritime Fund (NAT).

B.-Opinion of Council of State with No 71 issued on February 8, 1979 and with No 185 issued on March 15, 1979 with which regulated issues relating to permanent deprivation of seafaring.

C.- Concerning the interpretation of article 251 paragraph 1 (a) has been issued the legal opinion with No 10 issued on October 13, 1987 by the MMM Legal Adviser with which was accepted the Ministerial Decision with No 3973/F13 issued on October 30, 1987 according to, is determined the extent and the size of the commitment of the Disciplinary Council of a report prepared by ASNA as well as the procedure which must be followed in case of revealing new information and evidence during the hearing process, according to which are created doubts concerning the degree of fault of judged seaman.

Note 47. See PD 806/70 (A' 275) and RD 683/60 (A' 158).

Note 48. ASNA are three (3) A, B, and C are equivalent and operating in accordance with the provisions of LD $712 / 70$ (A' 237) and law 2575/98 (A' 23). Relative are also the MD with Nos 68108/14/70 issued on February, $1971,68777 / 2 / 79$ issued on June 7, 1979, 68108/81 issued on July 15, 1981, 14145/5/92 issued on July 24, 1992. ASNA are established by a decision issued by the Safety Navigation General Secretary [MD with No 1141.1/04 issued on July 14, 2011(B' 1611), article 1, Section A, sub paragraph 6,7]. They are constituted by seven (07) members (One President and six members) as also by relative number of deputies. ASNA are in quorum if is present the President and four members.

Note 49. As maritime accident according to article 1 of LD 712/1970 is determined:

1.- Total actual or imputed loss or Hellenic vessel or docked vessel.

2.- Abandon to insurers.

3.- Permanent or temporary abandonment of the ship by the crew.

4.- Loss or damage of the vessel or of the docked vessel cargo by a percentage more than a fourth of that.

5.- Serious damage from which came continuing trend of ship and

6.- loss of life or serious injury of a crew member or passenger.

Note 50. The exercise of this competence peculiar in characteristics of judicial police

Note 51. See article 2, paragraph 2 of the LD 712/1970.

This competence has been inherited by the Minister of Citizen Protection, (now MSA) to the Head of HCG according to the MD with No 1141.1/04 issued on July 14, 2011 (B' 1611), [article 1, paragraph B, sub paragraph 48].

Note 52. With the legal opinion with No 71/1979 issued by the Council of the State was accepted by the Minister of Mercantile Martine with the decision 68587/79 issued on August 20,1979, that there is possibility of referral case to ASNA (under preconditions which are mentioned in the opinion) in order to be investigated again maritime accident cases which have been referred to the criminal and disciplinary courts but has not yet issued final decisions by the courts. 
In practice the interest parties through the Navigation Safety Division (DAN) submit to the MSA new evidence which had not been considered during the first trial of the case in ASNA and in case that they are accepted by the Minister, then the referral case forwarded to ASNA which had issued the first report and the President of the Council shall charge the case in another rapporteur for obvious reasons, without being bound to charge the case to the initial rapporteur who had made the first suggestion for the case. Then is followed the same procedure of complaints in accordance with the applicable.

Note 53. See article 1 of law 4033/2011 (A' 264) paragraph 2a.

Note 54. See article 2 of law 2540/1998 (A' 211) and article 1 of law 3013/2002 (A' 102).

Note 55. See Korontzis, $\operatorname{Tr}(2012 \mathrm{c})$. Civil protection administration Systems in Hellas. Dioikitiki Enimerosi (quarterly journal of administration inspection), issue 61, p.p. 85-105 (in Hellenic).

Note 56. As Civil Defense is meant the organizing, leadership and mobilization of State political forces for its protection from any enemy kind of attacks and to combat any kinds of disasters particular in the political field (article 2 paragraph 1, law 2540/1998).

Note 57 . As Universal Defense is meant any active participation in national security by Hellenic nationals who can offer services for this and do not participate in the armed forces.

Note 58. See also article 15 of law 4058/2012 (A' 63) according to were amended provisions of law 4874/1929 (A' 339 ).

Note 59. Crises which are faced by HCG are ought to:

Natural disasters: Earthquakes, storms, hurricanes, fires, etc.

Violence action: terrorist acts (by organized criminal groups or by individuals), blackmail, kidnapping, hostage-taking, sabotage, strikes and demonstrations developed into violent, violence at sporting events etc.

Technological disasters: Prevention of operation or destruction of information systems - destruction of infrastructure etc.

Human errors: shipwrecks, maritime aircraft drops, pollution, vessels collisions etc

Note 60. Joint Rescue Coordination Center (JRCC-EKSED) has as mission to coordinate, and where is appropriate the management of maritime and air search and rescue operations, with appropriate procedures, infrastructure and means, in accordance with the provisions of the relevant contracts and manuals of IMO and ICAO, its function regulation [MD with No 1432.52/93, (B' 647) and 3221.4/07/05 (B' 702)] the instructions of the Air force General Staff (GEA) and the HCG Headquarters. The area of JRCC responsibility is identical to Athens FIR (article 2 of law 1844/89).

Note 61. According to article 2 of PD 67/2011 (A' 149) was established an Operational Branch in the HCG Headquarter consisting by the following divisions: Operations Planning, Floating and land Resources, Special Units, Air means and Weapons.

In article 4 of the law 3528/2007 (A' 122) was defined the "Establishment - Mission of HCG Operations Center". Specifically in the HCG Headquarter established Operation Center which its mission is the management, monitoring and coordinating of large-scale operations with the use of the infrastructure, the available means and HCG personnel, the monitoring of small-scale operations carried out by the local Port Police Authorities, as well as the provide of the necessary assistance to them except facts or search and rescue operations. Relative is the "Regulation of organization and function of HCG (KEPIX/HCG)", with No 09/09 which was ratified by the MD with No 7100/02/09 issued on May 21, 2009 by the Minister of Mercantile Marine, which was issued on implementation of article 4 of the law 3528/2007 (A' 122) and article 126 paragraph 3 sub paragraph (d) and (e) of law 3079/2002 (A'311).

Note 62. Articles 130 and next of law 3079/2002.

Note 63. (A'102), «Upgrading of civil protection and other provisions».

Note 64. Interministerial Committee for National Civil Protection Planning (DEESPP, article 4 of law 3013/2002).

Central Protection Policy Coordinating Center (KSOPP, article 5 of law 3013/2002).

Coordinating Prefectural Body (SNO, article 13, of law 3013/2002).

Responsibilities of Mayors-Presidents (STO, article 13, of law 3013/2002).

Civil Protection General Secretariat (article 6, of law 3013/2002). 
Civil Protection Operational Centre, [article 6, of PD 151/2004 (A' 107)].

Note 65. According to law 3536/2007 ( $\mathrm{A}^{\prime} 42$ ) and particular with article 27 paragraph b «the request of government agencies in the case (b) of paragraph 1, article 3 of the present, for assistance of other authorities, agencies and actors in the domestic or in the foreigner with purpose the combating of all kind destruction is submitted exclusively via the General Secretariat of Civil Protection».

Note 66. See Korontzis, Tr. (2009a). Administrative governmental reforms. The case of Ministry of Mercantile Marine, the Aegean and Island Policy (MMMAIP-ENANP)», Dioikitiki Enimerosi (quarterly journal of administrative inspection), issue 52, p.p. $31-57$ (in Hellenic) and Korontzis, Tr. (2010).Coast Guard and administrative experiments. Dimosios Tomeas, issue 269, p.p. 33-35 (in Hellenic). 